\title{
Circulation as Assessment: Collection Development Policies Evaluated in Terms of Circulation at a Small Academic Library
}

\author{
Debbi Dinkins
}

\begin{abstract}
At the root of all library acquisition decisions is the goal to add to the collection those materials that meet users' needs. Compiling circulation statistics is one way of assessing users' needs. This project seeks to assess the current collection development practices at Stetson University with respect to the circulation of books purchased in support of selected departmental curricula. Circulation statistics for books selected by five academic departments over a five-year period are compared with those of librarian selections in corresponding subject areas.
\end{abstract}

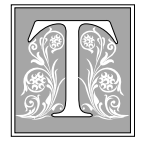

he process of allocating department and program funding for library materials is a complicated and time-consuming endeavor for acquisitions and collection development librarians in small academic libraries. Although many academic libraries have been able to increase their materials budgets in recent years, these increases have often failed to keep pace with the rising cost of materials. This decrease in buying power impacts libraries' ability to support the research needs of their users.

At the root of all library acquisition decisions is the goal to add to the collection those materials that will meet users' needs; compiling usage statistics is an effective way of assessing previous decisions and allows extrapolation for the future. Studies have been conducted to track the use, over time, of a sampling of circulating books. Larry Hardesty conducted two studies at DePauw University and at Eckerd College in the 1980s. At DePauw, Hardesty tracked all circulating books purchased over a six-month period $(2,031$ books) and found that " $80 \%$ of the ... circulation was accounted for by $30 \%$ of the books." ${ }^{1}$ At Eckerd College, he tracked purchased circulating books acquired during one budget year $(1,398$ books) and found that 34 percent of the books studied accounted for 80 percent of the total circulation. ${ }^{2}$

At Stetson University's main campus in DeLand, Florida, assigning materials budget amounts for university departments and programs is a highly refined process involving an allocation formula based on variables such as number of student majors and number of faculty in a department. There also is a general fund from which librarians make selections. 
Stetson University, primarily an undergraduate institution with a few master's programs, has a College of Arts \& Sciences, a School of Business Administration, and a School of Music. Stetson provides a microcosm in which to study the effectiveness of materials' selection by librarians and classroom faculty. ${ }^{3}$

\section{Academic Library Collection Development Practices}

In a literature survey on collection development policies, many articles confirmed that classroom faculty determine most of the selections made in small academic libraries. A survey cited in Library Journal in 1998 claimed that "virtually every library LJ surveyed relied on faculty when making purchasing decisions, and half of them ranked faculty as the number-one source." ${ }^{4}$ An earlier survey in 1997 stated that "the two most important reasons for selecting a title are relevance to curriculum, and requests by faculty." ${ }^{5}$ Teaching faculty's allegiance to their particular discipline or specialty, as well as to the research needs of their students, impacts

\section{The hypothesis of this study that circulation percentages of books selected departmental faculty will than circulation percentages of books selected similar subject areas.}

their selection decisions. "By definition and by tradition, the faculty are research specialists. Their primary loyalty is often to a profession rather than to the institution. The library, however, must assemble collections that serve narrow subdisciplines as well as the multidisciplinary needs of the community as a whole. Thus, the scope of faculty interests does not necessarily match those of the library." ${ }^{\prime 6}$

\section{Stetson's Collection Development Policy}

Academic departments are allocated funds based on a formula, taking into account number of majors, student contact hours, number of faculty, cost of materi- als in the field, and library use/research intensity of the field at Stetson. Participation of faculty in the development of the collection is highly encouraged. ${ }^{7}$ Each academic department designates a liaison responsible for coordinating, surveying, and collecting library material requests from other faculty in the department. These departmental requests come to the acquisitions librarian, who then approves the requests for ordering. Faculty requests almost always receive approval, with the rare question occurring about availability or cost. Faculty requests are purchased with departmental library materials budgets. The formula for departmental budget allocation is reevaluated periodically by the Library Administrative Team and by the University Library Committee. ${ }^{8}$

\section{Purpose and Hypothesis}

This project seeks to assess the current collection development practices of Stetson University's duPont-Ball Library with respect to circulation of books purchased in support of selected departmental curricula. Using the circulation data of books ordered, the study compares the circulation percentages of books selected by departmental faculty to those of books selected by librarians in the corresponding subject areas. Five-year data sets (1997-2001) of acquisitions data and circulation data were used to conduct the study. The hypothesis of this study is that circulation percentages of books selected by departmental faculty will be higher than circulation percentages of books selected by librarians in similar subject areas. If project results reject this hypothesis, the results will be used to help the selected departments' faculty to optimize library materials budgets and enhance selection techniques.

\section{Methodology}

\section{Choosing Departments to Study}

Departments were selected for this study based on the percentage of the departmental budget spent on circulating monographs in fiscal years 1999-2000 and 20002001. Stetson is somewhat unusual in that 
allocations to departments cover their journal subscriptions as well as monograph purchases, with journal subscription costs continuing every year. The study included departments with more than 50 percent of their budgets spent on circulating monographs. Based on this criterion, all natural science de-

TABLE 1

Departmental Monograph Expenditure Percentage

\begin{tabular}{lcc} 
Department & $\begin{array}{c}\mathbf{2 0 0 0 - 2 0 0 1} \\
\text { \% of Total Budget } \\
\text { on Circ. Monographs }\end{array}$ & $\begin{array}{c}\text { 1999-2000 } \\
\text { \% of Total Budget } \\
\text { on Circ. Monographs }\end{array}$ \\
\hline Art & $82 \%$ & $82 \%$ \\
English & $66 \%$ & $67 \%$ \\
History & $59 \%$ & $58 \%$ \\
Music & $66 \%$ & $50 \%$ \\
Political science & $64 \%$ & $65 \%$ \\
\hline
\end{tabular}

partments were excluded.

After consideration of all qualifying departments, the departments of art, English, history, music, and political science were chosen for study, based on their monographic selection percentages and on the ease of matching librarian selections to the subject matter. ${ }^{9}$ (See table 1.)

\section{Generating Departmental Selection Data}

Acquisitions records kept in the library's automated computer system (Sirsi Uni$\operatorname{corn}^{\circledR}$ ) generated lists of circulating monographs ordered by each department using its departmental library materials budget for five fiscal years. Each list was converted to a spreadsheet, with columns for order number, order line number (if applicable), fiscal year, author, title, OCLC number, number of charges (times circulated), and comments. (See table 2 for an excerpt from one of the spreadsheets.)

After the selection spreadsheets were constructed for each department for the fiscal years between 1996-1997 and 2000-
2001, each monograph title was checked in the Sirsi system for the number of times the title had circulated since 1997. Titles in the spreadsheet were matched to titles in the Sirsi system by comparing factors such as title, author, OCLC number, publication date, and acquisition date. Reference collection titles and missing titles were deleted from the spreadsheet. Each volume of multivolume sets that circulated more than once was entered separately, with notes in the Comments column about which volume was being represented. If an entire multivolume set had not circulated at least once, one line in the spreadsheet represented the whole set with a note in the Comments column.

With all titles in the spreadsheet matched to circulation data, the spreadsheet was sorted to display the titles in descending order, based on circulation. From the spreadsheet data, the percentages of titles checked out at least once and more than once were calculated. (See the

\begin{tabular}{|c|c|c|c|c|c|}
\hline \multicolumn{6}{|c|}{$\begin{array}{c}\text { TABLE } 2 \\
\text { Section of English Department Spreadsheet }\end{array}$} \\
\hline Order \# & Line \# & FY & Author & Title & Charges \\
\hline 99-006 & 54 & 9899 & Albright, Daniel & Quantum poetics & 25 \\
\hline $98-269$ & 49 & 9798 & Peterson, Nancy J. & $\begin{array}{l}\text { Toni Morrison: critical and } \\
\text { theoretical approaches }\end{array}$ & 11 \\
\hline $98-055$ & 35 & 9798 & Furman, Jan. & Toni Morrison’s fiction & 9 \\
\hline $98-371$ & 10 & 9798 & $\begin{array}{l}\text { Petry, Alice Hall, } \\
\text { 1951- }\end{array}$ & Critical essays on Kate Chopin / & 9 \\
\hline $98-269$ & 13 & 9798 & Kaplan, Carla & $\begin{array}{l}\text { The erotics of talk: women's writing } \\
\text { and feminist paradigm }\end{array}$ & $\operatorname{ng}$ \\
\hline
\end{tabular}




\begin{tabular}{|ll|}
\hline \multicolumn{2}{|c|}{$\begin{array}{c}\text { TABLE } 3 \\
\text { LC Classification for Department/ } \\
\text { Subject Area }\end{array}$} \\
\hline \hline Department/ & LC \\
Subject Area & Classification \\
\hline Art & $\mathrm{N}$ \\
English & P-PA, PR-PS, PZ \\
History & C, D, E, F \\
Music & $\mathrm{M}$ \\
Political Science & $\mathrm{J}, \mathrm{K}$ \\
\hline
\end{tabular}

Results section for these percentages.) The same process was followed for each of the five selected departments.

\section{Generating Librarian Selection Data}

Acquisitions data were examined from the library's general fund, which is used to order items selected by librarians. For the five fiscal years studied, circulating monographs ordered by librarians were drawn from the Sirsi system, and the data were entered into spreadsheets for each of the five department subject areas. The circulating monographs were matched to each subject area based on the LC classification associated with the monograph. Table 3 shows the LC classifications used for each studied subject area.

As with the departmental selections, each librarian-selected title was checked in the Sirsi system for number of times circulated since 1997. The spreadsheets for each subject area were sorted in descending order, based on the number of times circulated. Percentages of selections that circulated at least once and more than once were calculated based on the spreadsheet data.

\section{Results}

Table 4 shows the approximate total number of circulating books selected by departmental faculty and librarians in each subject area between 1997 and 2001. ${ }^{10}$

Art

Based on the data, the art department faculty performed best in selecting books that circulated at least once. Over the last two years of the study, the art department spent an average of 82 percent of its library materials budget on the book format. Sixty-three percent of the total number of books selected during the fiveyear period circulated at least once, and 36 percent circulated more than once. $\mathrm{Li}$ brarians also selected effectively in the art category, with 54 percent of the books circulating at least once, and 36 percent circulating more than once (table 5). The departmental faculty's high circulation percentage is even more impressive considering that art department faculty ordered almost eight times as many circulating art books during the same time period as the librarians did.

\section{English and Political Science}

In the subject areas of English and political science, the departmental faculties and the librarians compare evenly in selection circulation percentages for books circulating at least once. During the last two years of the study, the English department spent about 67 percent of its library materials budget on the book format, and the political Science department spent about 65 percent. During the five years studied, the English faculty selected nearly three times as many books as the librarians in that subject area. The political science faculty selected ten times as many books as the librarians during the same time period. Interestingly, the circulation percent-

\begin{tabular}{|lcc|}
\hline \multicolumn{3}{|c|}{ TABLE 4} \\
$\begin{array}{c}\text { Number of Selections by Departmental } \\
\text { Faculty and Librarians }\end{array}$ \\
\hline \hline & $\begin{array}{c}\text { Total Number } \\
\text { of Selections } \\
\text { by Departmental }\end{array}$ & $\begin{array}{c}\text { Total Number } \\
\text { of Selections } \\
\text { by Librarians } \\
\text { in Subject Area }\end{array}$ \\
& Faculty & in \\
& 1,433 & 512 \\
English & 598 & 80 \\
Art & 1,433 & 512 \\
English & 439 & 288 \\
History & 635 & 23 \\
Music & 1,086 & 104 \\
Political science & & \\
\hline
\end{tabular}


TABLE 5

Circulation Percentages for Departmental Faculty and Librarian Selections

\begin{tabular}{lcc|cc}
\hline \hline & \multicolumn{2}{c|}{$\begin{array}{c}\text { Selections Circulating } \\
\text { At Least Once }\end{array}$} & \multicolumn{2}{c|}{$\begin{array}{c}\text { Selections Circulating } \\
\text { More Than Once }\end{array}$} \\
\hline $\begin{array}{l}\text { Department/ } \\
\text { Subject Area }\end{array}$ & $\begin{array}{c}\text { Departmental } \\
\text { Faculty }\end{array}$ & Librarians & $\begin{array}{c}\text { Departmental } \\
\text { Faculty }\end{array}$ & Librarians \\
\hline Art & $63 \%$ & $54 \%$ & $36 \%$ & $36 \%$ \\
English & $43 \%$ & $46 \%$ & $23 \%$ & $22 \%$ \\
History & $44 \%$ & $58 \%$ & $18 \%$ & $28 \%$ \\
Music & $46 \%$ & $70 \%$ & $25 \%$ & $48 \%$ \\
Political science & $45 \%$ & $48 \%$ & $24 \%$ & $31 \%$ \\
\hline
\end{tabular}

ages for both groups' selections vary by seven percentage points or less. As shown in table 5, the largest variation occurs in a comparison of political science faculty selections and librarian selections that circulated more than once, with 24 percent of the departmental faculty selections circulating more than once and 31 percent of the librarians' selections circulating more than once.

\section{For selections made art depart- ment faculty, 80 percent of the circulation was accounted for percent of the books studied

\section{History}

In history, the librarians' selections have circulated more frequently than the departmental selections. History faculty selected almost twice as many circulating books as librarians during the five-year time period. As shown in table 5, the librarians' selections circulated at a higher percentage, with 58 percent circulating at least once and 28 percent circulating more than once, compared to the department faculty's 44 percent and 18 percent, respectively. During the last two years of the study, the history department spent about 59 percent of its library materials budget on the book format.

\section{Music}

The music department's faculty spent an average of 58 percent of their general library materials budget on the book format during the last two years of the study.
An additional library materials fund exists for the School of Music that is primarily used for purchasing scores and recordings and was not included in the study. At Stetson, a music librarian acts as liaison between the library and the School of Music faculty for selection of materials. The music faculty and the music librarian selected about 1,500 more circulating music books than did the other librarians. However, the librarians' selections circulated at a higher percentage rate than those of the faculty, with 48 percent of the librarians' selections circulating more than once, compared to a 25 percent circulation rate for the faculty selections (table 5). Because of the wide gap between the numbers of books selected by the two groups, more study and attention should be given to music book selection before collection development conclusions can be drawn. Also, it should be noted that a portion of the music circulating books, including all selected by the music librarian, were housed in a separate music library until 2001. With the relocation of those books to the main library, circulation rates may increase because the books are now more accessible to all library users.

\section{Comparison with Other Studies}

As stated earlier, Hardesty's study at DePauw University compared classroom faculty selections and librarian selections. His study divided the use of circulating books into the following four categories: heavy use (more than eleven circulations); 


\begin{tabular}{|lcc|}
\hline \multicolumn{2}{|c|}{$\begin{array}{c}\text { TABLE } 6 \\
\text { Percentages of Selections by Stetson Departmental Faculty and Librarians } \\
\text { Accounting for 80\% of Circulation }\end{array}$} \\
\hline \hline & Department Faculty & Librarians \\
\hline Dept./Subject Area & Percentage of Selections & Percentage of Selections \\
& Accounting for $80 \%$ & Accounting for $80 \%$ \\
of Circulation & of Circulation \\
\hline Art & $34 \%$ & $29 \%$ \\
English & $25 \%$ & $25 \%$ \\
History & $29 \%$ & $33 \%$ \\
Music & $25 \%$ & $39 \%$ \\
Political science & $25 \%$ & $28 \%$ \\
\hline
\end{tabular}

moderate use (six to ten circulations); light use (one to five circulations); and none. Twenty-six percent of the librarianselected books were either moderately or heavily used. Only 13 percent of the classroom faculty-selected books were in these two categories. ${ }^{11}$ By comparison, the circulation percentages of both librarian-selected and classroom faculty-selected books at Stetson were much lower in the moderately and heavily used categories. Neither group had more than five percent of their selections circulate six or more times. Because DePauw and Stetson are comparably sized universities, the difference in use possibly can be attributed to longer checkout periods. Typically, at the time of Hardesty's study (1972-1978), the checkout period for students was two weeks. However, Stetson students have a one-month checkout period and books circulate to Stetson faculty for the entire semester.

Hardesty's study at DePauw found that 80 percent of circulation was accounted for by 30 percent of the books studied. ${ }^{12}$ In his replication study at Eckerd, Hardesty found that 80 percent of the circulation was accounted for by 34 percent of the books studied..$^{13}$ In this Stetson study, for selections made by art department faculty, 80 percent of the circulation was accounted for by 34 percent of the books studied (table 6). Other departmental faculty selections had lower percentages accounting for 80 percent of the circulation. Librarian selections in music had 39 percent of the books selected accounting for 80 percent of the circulation. Lower percentages accounted for 80 percent of the circulation in other subject areas. These percentages are very similar to the percentages in both Hardesty studies.

\section{Recommendations \\ Departmental Collection Development Changes}

No change is recommended in collection development practices for the art department. Both departmental faculty and librarians are selecting effectively in this area, with circulation percentages at or above 36 percent. Also, no change is recommended for collection development practices in the English subject area. Both departmental faculty and librarians are selecting materials with circulation percentages above 22 percent.

In political science, there was a higher percentage of librarian selections circulating more than once, with 31 percent for librarians and 24 percent for departmental faculty. In history, librarian selections circulating more than once also circulated more frequently than departmental faculty selections in the same category, with 28 percent for librarians and 18 percent for departmental faculty. Librarians should work more closely with political science and history faculty to enhance their selection choices. By exposing them to more diverse sources of book reviews (e.g., subject-specific journals) and by encouraging the faculty to select books 
more specific to the Stetson curriculum and class assignments, the departments should be able to select books that circulate more frequently. Course-specific, classroom-based surveys, as developed by Patricia Weaver, might offer departmental faculty some insight into selection in their fields. ${ }^{14}$ "Classroom-based surveys of students and interviews with their instructors should be an ongoing collection-building tool for academic libraries, where space and budgetary restraints often limit the number of books that can be made available at any one time." ${ }^{15}$ Moreover, the librarians should offer to work with political science and history faculty in developing research methods and strategies for their students, using a broader spectrum of the library's circulating materials.

Because of the low number of circulating books selected in the music subject area by librarians, no specific conclusions can be drawn on the effectiveness of music collection development by non-music librarians. Based on local experience, the circulation percentages of musical scores and recordings selected by music department faculty should be much higher than for music books. Further study should be conducted on music scores and recordings circulation to determine circulation percentages and to compare the figures with those of circulating music books.

\section{Conclusions}

The hypothesis of this study theorized that circulation percentages of books selected by departmental faculty would be higher than circulation percentages of books selected by librarians in similar subject ar- eas. Based on circulation percentages of selections circulating more than once (table $5)$, the hypothesis is rejected. The circulation percentages for librarians' selections circulating more than once were equal to or higher than those of departmental faculty selections in all subject areas studied.

The librarians and staff should open a dialogue with the history, political science, and music faculty about the use of the books they are currently ordering for the library. As Hardesty concluded from the study at Eckerd College, "most classroom faculty have received little or no formal education on how to select library materials that are appropriate for the undergraduate student or on how to encourage undergraduate student use of these materials." 16 Better communication between the librarians and the faculty of all departments will enhance the selection accuracy of the departmental faculty and the librarians in those subject areas. The results of this project will be made available to all five departments.

The data generated by this study may be of interest for future studies. The raw data could be used to gather more specific information about areas such as the following: librarian selections over the fiveyear study period; circulation performance of large standing order and/or continuation sets; general trends in selection among librarians and departmental faculty; comparison to Choice reviews (Choice card reviews are sent to all departments for use in the selection process). The study data will be useful in the future in making selection and acquisition decisions for the library and will be used as a basis for future studies or projects.

\section{Notes}

1. Larry Hardesty, "Use of Library Materials at a Small Liberal Arts College," Library Research 3 (1981): 261-82.

2. - - - "Use of Library Materials at a Small Liberal Arts College: A Replication," Collection Management 10 (1988): 61-80.

3. For many years, some departments had to cut back on their monographic library purchases because of lack of funding and failure of budget growth to match inflation. New programs developed over the past few years have had no library budgets and been forced to rely on existing departmental budgets to fund their library needs for research and curricular support.

4. Barbara Hoffert, "Book Report, Part 2: What Academic Libraries Buy and How Much They Spend," Library Journal 123 (Sept. 1, 1998): 144-46. 


\section{Circulation Assessment 5}

5. James H. Sweetland and Peter G. Christensen, "Developing Language and Literature Collections in Academic Libraries: A Survey," Journal of Academic Librarianship 23 (Mar. 1997): $119-25$.

6. Lawrence Thomas, "Tradition and Expertise in Academic Library Collection Development," College and Research Libraries 48 (Nov. 1987): 487-93.

7. Stetson University Library, "Acquisitions and Collection Development," Dec. 2001. Available online from http://www.stetson.edu/departments/library/colldev.html.

8. - - - "Collection Development and Organization Policies," Dec. 2001. Available online from http://www.stetson.edu/departments/library/TSManual.html.

9. It should be noted that in recent years, monographs ordered by political science faculty have gone unordered because of increasing journal subscription costs in this subject area.

10. Numbers are approximate because some multivolume sets with none of the volumes circulating are represented as one title with one line in the spreadsheet.

11. Hardesty, "Use of Library Materials at a Small Liberal Arts College," 275.

12. Ibid., 266-67.

13. Hardesty, "Use of Library Materials at a Small Liberal Arts College: A Replication," 67.

14. Patricia Weaver, "AStudent-centered Classroom-based Approach to Collection Building," Journal of Academic Librarianship 25 (May 1999): 202-10.

15. Ibid., 208.

16. Hardesty, "Use of Library Materials at a Small Liberal Arts College: A Replication," 78. 